\title{
HNMP-1: A Novel Hematopoietic and Neural Membrane Protein Differentially Regulated in Neural Development and Injury
}

\author{
Laurel M. Bolin, Tom McNeil, Linda A. Lucian, Brigitte DeVaux, Karin Franz-Bacon, Daniel M. Gorman, \\ Sandra Zurawski, Richard Murray, and Terrill K. McClanahan
}

DNAX Research Institute, Palo Alto, California 94304-1104

\begin{abstract}
The hnmp-1 (hematopoietic neural membrane protein) gene encodes a protein with striking similarity to the tetratransmembrane-spanning protein encoded by pmp22. $h n m p-1$ was cloned from an elutriated human monocyte library and is expressed in various human hematopoietic and lymphoid lineages as well as adult mouse spleen and thymus. In the mouse nervous system, HNMP-1 mRNA is temporally expressed by Schwann cells during sciatic nerve myelination. Dorsal root ganglia sensory and spinal cord $\alpha$-motoneurons acquire HNMP-1 protein selectively throughout development. In the
\end{abstract}

fiber tracts of the spinal cord and in sciatic nerve, HNMP-1 protein is axon-associated. Additionally a rapid and sustained level of HNMP-1 expression is observed in response to acute PNS injury. HNMP-1 is constituitively induced in sciatic nerve of Trembler $\mathrm{J}$ mice, which are mutant for pmp22 and have a demyelinating/hypomyelinating phenotype. The expression pattern of HNMP-1 suggests a possible role for this molecule during active myelination.

Key words: Schwann cell; DRG; sensory neuron; motoneuron; regeneration; PMP22; hematopoiesis; development
Analogies between hematopoiesis and neuropoiesis have been drawn because of shared receptor-ligand systems (Patterson, 1992) and also from the concept of a multipotential "stem cell" ontogeny (Anderson, 1989; Metcalf, 1991). Sensory (Cheema et al., 1994) and motoneurons (Martinou et al., 1992) express the gp130 receptor that combines with specific receptors whose activation provides neurotrophic signals (Taga et al., 1989; Hibi et al., 1990; Gearing et al., 1992; Davis et al., 1993). These same signals participate in the inflammatory cascade in monocytes (Dinarello, 1989; Arai et al., 1990). The c-kit ligand Steel Factor is essential for hematopoietic stem cell survival and is a survival factor for sensory neurons (Hirata et al., 1993; Carnahan et al., 1994). Macrophage and Schwann cells perform similar scavenger functions in degenerating peripheral nerve (Stoll et al., 1989) and secrete cytokines in response to similar stimuli (Bergsteinsdottir et al., 1991; Rotshenker et al., 1992; Bolin et al., 1995); however, structural proteins that may be shared between the hematopoietic and nervous systems have been less well characterized.

In Schwann cells, PMP22 is an integral membrane protein that is a component of the peripheral myelin sheath (Snipes et al., 1992). Myelin protein $P_{0}$ (Lemke, 1993) and connexin32 (Scherer et al., 1995) are structural proteins essential for membranemembrane interactions in myelin compaction. Mutations or duplications in the genes encoding these three myelin proteins result in Charcot-Marie-Tooth type I syndrome (CMT) (Chance and Fischbeck, 1994). In addition, PMP22, localized to human chromosome 17 (Patel et al., 1992), is widely expressed in non-neural

Received Sept. 6, 1996; revised April 24, 1997; accepted May 7, 1997.

DNAX Research Institute is supported by Schering-Plough Corporation. We thank Dr. Gerard Zurawski for critical reading of this manuscript, Dr. Bob Miller for helpful discussions on spinal cord development, Dr. Carl Figdor for the gift of human elutriated monocytes, and Dr. Ursula Jeffry for help with FACS analysis.

Dr. DeVaux's present address: Genentech, 460 Point San Bruno Boulevard, South San Francisco, CA 94080.

Correspondence should be addressed to Dr. Richard Murray, DNAX Research Institute, 901 California Avenue, Palo Alto, CA 94304-1104

Copyright (C) 1997 Society for Neuroscience $0270-6474 / 97 / 175493-10 \$ 05.00 / 0$ tissues (Baechner et al., 1995; Parmantier et al., 1995) and was originally characterized as a growth arrest factor, gas3, in fibroblasts (Manfioletti et al., 1990). Connexin32, which is X-linked in humans, is also a myelin component of CNS oligodendroglia (Bergoffen et al., 1993). $\mathrm{P}_{0}$, localized to human chromosome 1 (Hayasaka et al., 1993), is expressed exclusively by Schwann cells (Lemke and Axel, 1985). Mapping studies in humans afflicted with CMT-like neuropathies have shown that mutant genes other than PMP22, $P_{0}$, and connexin32 can cause CMT1 or the axonal neuropathy CMT2 (Chance and Lupski, 1994; Patel and Lupski, 1994).

We describe the cloning and characterization of a new member of the PMP22 family, HNMP-1 (hematopoietic neural membrane protein). HNMP-1, cloned from elutriated human monocytes, has a 44\% amino acid homology to PMP22 in both mice and humans. It is structurally homologous to PMP22, with a predicted tetra-spanning cell membrane topology. Amino acid moieties in which mutations lead to the CMT1A neuropathy in humans (Patel et al., 1992; Valentijn et al., 1992; Roa et al., 1993a,b) and the Trembler phenotype in mouse (Suter et al., 1992b) are conserved in HNMP-1. Although hnmp-1 is homologous to pmp22 in sequence and predicted structure, its tissue-specific expression and regulation are distinct. In addition to possible roles in the hematopoietic system, characterization of mouse HNMP-1 in PNS development and in acute and chronic sciatic nerve lesions suggests a function in axon-Schwann cell communication in active myelination.

\section{MATERIALS AND METHODS}

Cloning of hnmp-1

Library construction. RNA was isolated by standard techniques from elutriated human peripheral blood monocytes stimulated for 1, 2, 6, 12, and $24 \mathrm{hr}$ with lipopolysaccaride (LPS) $(5 \mu \mathrm{g} / \mathrm{ml}$ ) (Sigma, St. Louis, MO), interferon $\gamma(\gamma \mathrm{IFN})(200 \mathrm{U} / \mathrm{ml})$ (Schering Plough, Kenilworth, $\mathrm{NJ}$ ), and anti-interleukin-10 (IL-10) antibody (10 $\mu \mathrm{g} / \mathrm{ml})(\mathrm{DNAX})$ and then pooled. Poly $\left(\mathrm{A}^{+}\right)$RNA was selected using oligotex beads (Qiagen, Chatsworth, CA). A cDNA library was constructed using this mRNA by 
oligo-dT priming using the Superscript cDNA synthesis kit (Life Technologies, Gaithersburg, MD). DNA from randomly selected recombinant clones was sequenced using an automated DNA sequencer (Applied Biosystems/Perkin-Elmer, Foster City, CA).

Cloning of human hnmp-1. To isolate full-length candidates of hnmp-1, a 25 bp oligonucleotide was synthesized (5'-GCATCATCTACATCCACCTACGGAAG- $3^{\prime}$ ) and labeled at the $5^{\prime}$ end with polynucleotide kinase and $\gamma^{32} \mathrm{P}$ ATP (Amersham, Arlington Heights, IL) (Sambrook et al., 1989). This probe was hybridized to colony filter lifts of the original activated monocyte library at $42^{\circ} \mathrm{C}$ in $0.5 \mathrm{M} \mathrm{Na}_{2} \mathrm{HPO}_{4}+7 \%$ SDS $(\mathrm{v} / \mathrm{v})+0.5 \mathrm{~mm}$ EDTA, pH 8.0 (Sigma). Filters were washed three times for $20 \mathrm{~min}$ each at $42^{\circ} \mathrm{C}$ in $0.2 \times \mathrm{SSC}+0.1 \% \mathrm{SDS}$, and then exposed to Biomax film (Kodak, Rochester, NY) at $-80^{\circ} \mathrm{C}$ with an intensifying screen. The DNA sequence was deposited in GenBank, accession number U87947.

Cloning of mouse hnmp-1. To isolate the mouse homolog, a 318 bp fragment was generated by PCR using two primers (sense: 5' -TGGCTGAAGGCGGTGCAGGTCCTCATGG-3'; antisense: 5'-ACGGGGCGTTCACTCCCGCTTCCGTAGG-3') and the original cDNA clone of $h n m p-1$ as a template. This fragment was gel-isolated, labeled with ${ }^{32} \mathrm{P}$ dCTP by random prime labeling (Prime-it kit, Stratagene, LaJolla, CA), and hybridized at $65^{\circ} \mathrm{C}$ as described above to colony lifts of a mouse RAW 264.7 monocyte cell line, stimulated $4 \mathrm{hr}$ with LPS. The DNA sequence was deposited in GenBank, accession number U87948.

Cloning of mouse genomic hnmp-1. The entire $\sim 740 \mathrm{bp}$ insert of mouse hnmp-1 was used as a probe to identify the mouse genomic clone. A $\lambda 129$ genomic library (Stratagene) was screened by hybridization, and positive clones were isolated and subcloned into a plasmid vector and exon/intron boundaries were determined by DNA sequencing.

\section{Southern analysis of $c D N A$ libraries}

Library construction. cDNA libraries were constructed from cell types and fetal tissues, each from $2 \mu \mathrm{g}$ of high quality mRNA as described above. Each library was quality-controlled by three criteria. (1) Alkaline gel analysis of the first-strand synthesis revealed a size range of cDNA from $>0.5-5 \mathrm{~kb}$, indicating high quality RNA and a good predictor of large insert sizes in the final library. (2) After ligation of $100 \mathrm{ng}$ of cDNA, the number of independent clones was $>1 \times 10^{6}$ clones before amplification. (3) Sequence analysis of randomly selected clones from each library revealed a high proportion of full-length clones, and only very low levels of genomic or ribosomal RNA contamination $(<5 \%)$ (data not shown). We found that although standard RNA blot analysis of gene expression levels is somewhat more sensitive, a positive signal in a cDNA library is roughly comparable to RNA analysis, particularly in judging the presence or absence of a particular gene in a certain cell type or tissue. Large scale plasmid DNA preparation of amplified libraries was performed using a Giga prep (Qiagen, Chatsworth, CA).

Southern analysis. DNA $(5 \mu \mathrm{g})$ from the primary amplified cDNA library was digested with NotI and SalI (Boehringer Mannheim, Indianapolis, IN) to release the inserts, run on a $1 \%$ agarose gel, and transferred to a nylon membrane (Schleicher and Schuell, Keene, NH). Blots were probed with a 318 bp fragment as described.

\section{$R N A$ and Northern analysis}

Tissue expression analysis. Adult Swiss Webster mice (Simonsen Labs, Gilroy, CA) were euthanized in a $\mathrm{CO}_{2}$ atmosphere, and tissues were dissected. Pregnant Swiss Webster mice were euthanized at $15 \mathrm{~d}$ after coitus, and embryonic tissues were dissected. Sciatic nerves of Swiss Webster pups were dissected at various postnatal time points, as were C57BL $/ 6$ and C57BL/6-Tr ${ }^{\mathrm{J}}$ sciatic nerves (Jackson Labs, Bar Harbor, $\mathrm{ME}$ ). Tissues were either snap-frozen for RNA isolation or frozen in OCT medium (Miles, Elkhart, IN) for cryostat sectioning. Total cellular RNA was isolated from tissues by the RNAzol method (Teltest, Friendswood, TX).

Primary cell expression analysis. E15 Schwann cells were isolated from dorsal root ganglia (DRG) that were minced in PBS, washed twice in F12 media, and cultured at $37^{\circ} \mathrm{C}, 5 \% \mathrm{CO}_{2}$ in $\mathrm{F} 12$ media $+10 \%$ fetal calf serum on laminin $(10 \mathrm{mg} / \mathrm{ml})$-coated plastic plates (all from Life Technologies). DRG were removed after Schwann cells migrated from the explant. After Schwann cells reached confluency (10-12 d), they were characterized as described (Zhang et al.,1995) using rabbit anti-S100 $\beta$ antisera (Sigma). Microglia were isolated from E15 cortex as described (Neuhaus and Fedoroff, 1994). Meninges were removed, corteses were minced in F12 media $+10 \%$ FCS, triturated, and passed through $50 \mu \mathrm{m}$ nylon mesh. Single cell suspensions were cultured in slowly rotating flasks at $37^{\circ} \mathrm{C}, 5 \% \mathrm{CO}_{2}$ overnight. The following day floating cells were removed, and adherent cells were cultured to confluency (14-16 d). Peritoneal exudate cells (PECs) were isolated by peritoneal lavage and snap-frozen before RNA isolation. For monocytes derived from PECs, PECs were washed twice in RPMI media $+10 \%$ FCS and counted, and adherent cells were cultured as above with the addition of either $10 \mu \mathrm{g} / \mathrm{ml}$ recombinant mouse granulocyte macrophage colony stimulating factor (GM-CSF) (DNAX) or $20 \%$ (v/v) L cell-conditioned medium. For bone marrow-derived monocytes, whole marrow was flushed from femurs, and red cells were lysed by osmotic shock and cultured under the same conditions as for PEC monocytes.

Northern blots. Total RNA ( $\sim 10 \mu \mathrm{g} / \mathrm{lane})$ was separated on formaldehyde gels and transferred to positively charged nylon membranes (Amersham). The addition of ethidium bromide $(1 \mathrm{mg} / \mathrm{ml})$ to gel loading buffer permitted assessment of the amount of RNA that was transferred to the membrane. A $380 \mathrm{bp}$ restriction fragment of mouse HNMP-1 cDNA was radiolabeled and hybridized as described (Bolin et al., 1995). The size of the mouse HNMP-1 messenger RNA was determined by correlation with RNA sizing ladder $(5 \mu \mathrm{g} / \mathrm{lane})$ loaded on the same gel (Boehringer Mannheim). The blot containing a $14 \mathrm{~d}$ time course of RNA isolated from sciatic nerve tissue distal to injury was stripped after HNMP-1 autoradiography and reprobed as described with a radiolabeled 392 bp restriction fragment of mouse PMP22 cDNA.

\section{Antisera and Western analysis}

Antisera. A synthetic peptide (HTEEILAKHPSGG conjugated to KLH) encoding the putative second extracellular loop of mouse HNMP-1 was the immunogen for rabbit antisera (Genemed Biotechnologies, South San Francisco, CA). Specific IgG was affinity-purified against the synthetic peptide linked to 6-aminohexanoic acid $N$-hydroxysuccinimide ester Sepharose support (Sigma).

Transfection. Expression plasmids for HNMP-1 and PMP22 proteins with C-terminal FLAG-tags were constructed by inserting HindIII- and XhoI-treated (Boehringer Mannheim) products of PCR reactions using HNMP-1 and PMP22 cDNAs as templates and the primer pairs 5'CTCCTGCCCTAAGCTTGACATCTGGCAGCC-3' + 5'-CGTCGTCGTCTCGAGTTATTTATCATCATCATCTTTATAATCTTCACGTTTCCGCAGGTGGATGTAGACAATGCCGCT-3', 5'-CCGCTCCTCTGATCCCGAGCCAAGCTTCCAGCCA-3' + 5'-CGTCGTCGTCTCGAGTTATTTATCATCATCATCTTTATAATCTTCGCGTTTCCGCAGGATCACATAGATGATACCACTGAGG-3', respectively, into HindIII- and XhoI-treated pCDM8 (Invitrogen, Portland, OR). Plasmid DNAs (15 $\mu \mathrm{g}$, maxiprep kit, Qiagen) were used to transfect $10^{7}$ COP5 cells (Dailey and Basilico, 1985) using standard methodologies. Three days after transfection, cells were lysed for protein analysis.

Western blots. Protein samples were mixed with Tricine SDS sample buffer containing 5\% 2-mercaptoethanol, subjected to SDS-PAGE $(10 \%$ Tricine gel), and transferred to nitrocellulose (all from Novex, San Diego, CA). One filter was incubated with $10 \mu \mathrm{g} / \mathrm{ml}$ anti-FLAG M2 antibody (IBI, New Haven, CT) according to the manufacturer's instructions. A duplicate filter was incubated with affinity-purified antiHNMP-1 peptide-derived antisera at 1:50 followed by anti-rabbit IgGHRP antibody (1:1000) (Promega, Madison, WI). Wash and incubation buffer were SuperBlock containing 0.05\% Tween 20 (Pierce, Rockford, IL). Immunoreactivity was visualized with the Enhanced Chemiluminescence Detection System (Amersham). Prestained protein molecular weight standards were SeeBlue (Novex).

\section{Regeneration protocol}

Eight-week-old female Swiss Webster mice were anesthetized by isoflurane inhalation (Hawk and Leary, 1995), and a sciatic nerve crush injury method was adapted (Bolin and Shooter, 1993), with the addition of $1 \mu \mathrm{l}$ of latex fluorospheres (Molecular Probes, Eugene, OR) delivered to the crush site for detection by fluorescence 12 weeks after injury. At various times after crush, animals were euthanized as described above, and $4 \mathrm{~mm}$ segments of nerve distal to the crush site were removed. Segments of the sham-operated contralateral nerve were also removed. Tissue was snapfrozen for RNA isolation or frozen in OCT medium for cryostat sectioning.

\section{Immunohistochemistry}

The following unfixed, frozen tissues were serial-sectioned at $6 \mu \mathrm{m}$ : E12, adult spinal cord, DRG, naive adult sciatic nerve, and sciatic nerve distal to the crush injury, at various times after crush. Immunohistochemistry methods were as described (Litton et al., 1994). Affinity-purified rabbit 
A.

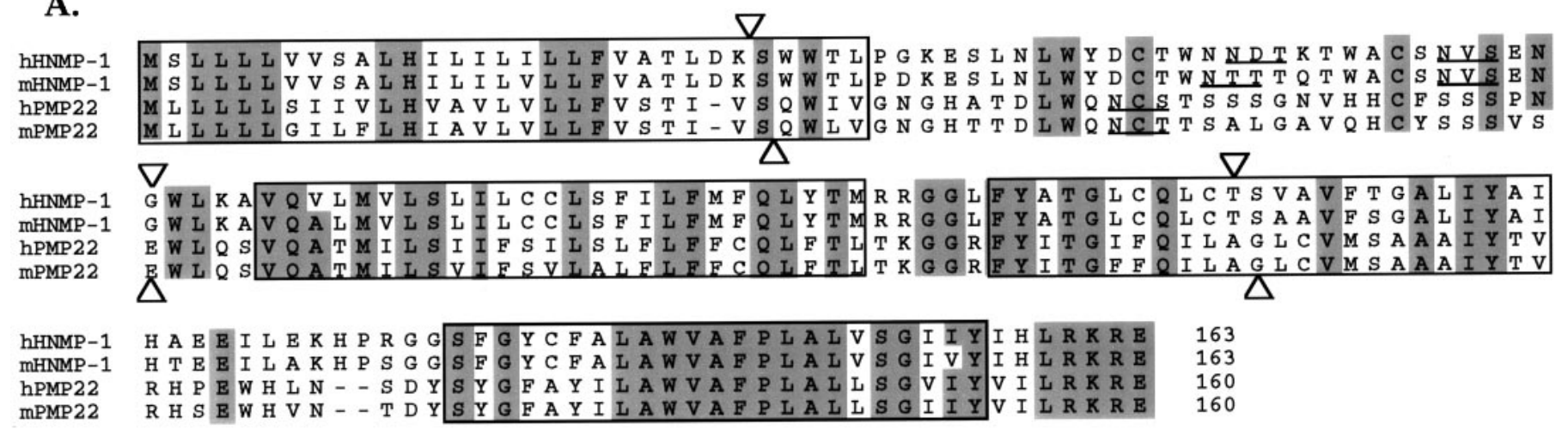

B.
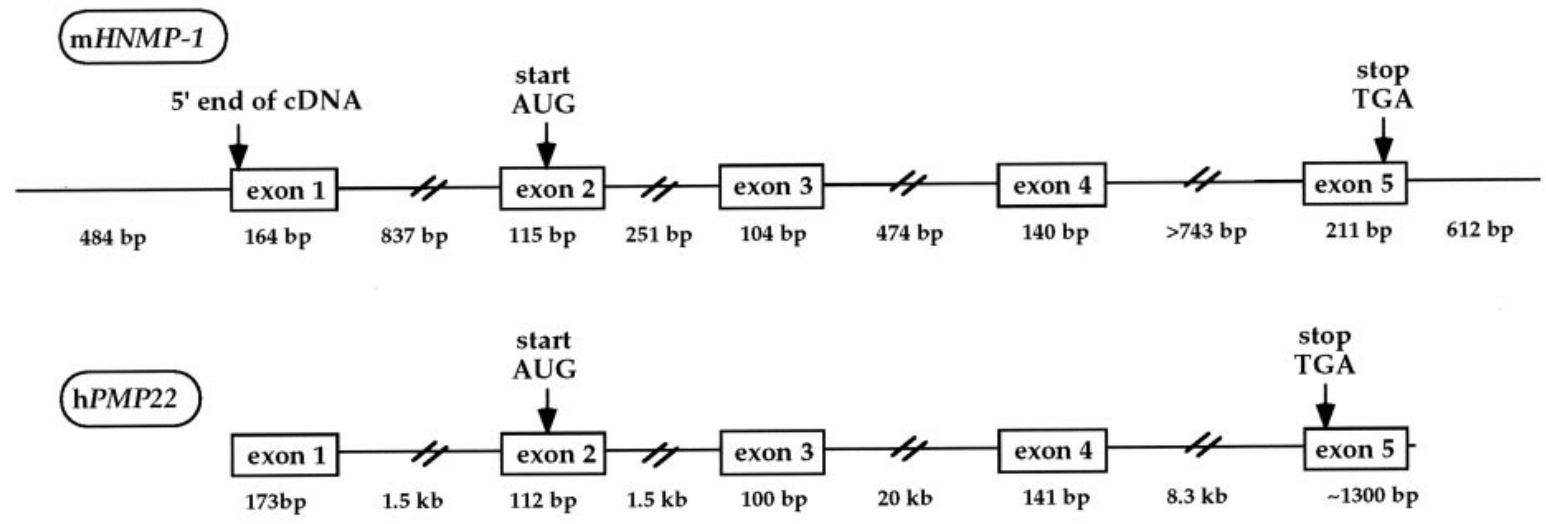

Figure 1. Comparison of human and mouse HNMP-1 and PMP22 amino acid sequence and genomic organization. $A$, Amino acid identities between HNMP-1 and PMP22 are marked with gray boxes. The four membrane-spanning regions are outlined in black. Exon/intron boundaries are denoted by triangles. Possible $N$-linked glycosylation sites are underlined. $B$, The sizes of exons and introns are shown. Hnmp-1 intron 4 was estimated to be $\sim 1.4 \mathrm{~kb}$, $743 \mathrm{bp}$ of which was sequenced. The genomic organization of the human PMP22 gene is shown to illustrate the high degree of overall conservation of genomic structure between these two genes.

anti-HNMP-1 synthetic peptide-derived antisera was used at 1:100. For inhibition, synthetic peptide $(10 \mu \mathrm{g} / \mathrm{ml})$ was preincubated with antisera for $30 \mathrm{~min}$ at room temperature before tissue section incubation. The immunoreactivity was amplified using a goat peroxidase anti-peroxidase method according to the manufacturer's instructions (Sternberger Monoclonals, Baltimore, MD). The antibody complex was visualized with metal-enhanced diaminobenzadine (Pierce).

\section{RESULTS}

\section{Cloning and sequencing of hnmp-1}

A cDNA library was constructed from elutriated human peripheral blood monocytes cultured in the presence of the monocytic stimulation molecules $\gamma$ IFN, LPS, and blocking antibodies for IL-10 for 1, 2, 6, 12, and $24 \mathrm{hr}$ and then pooled. Randomly selected cDNA clones were analyzed by automated DNA sequencing. The resulting nucleotide sequences were searched against GenBank public databases to determine known and novel sequences. The clone hnmp-1 was found by BlastN (Altschul et al., 1990) searches to be novel and to have significant nucleotide homology with both mouse and human PMP22 cDNAs. BlastP analysis (Altschul et al., 1990) of a putative open reading frame showed a high degree of homology with PMP22 (44\% amino acid identity) and revealed that the $\sim 500$ bp insert of this clone was not full length. When the original cDNA library was reprobed, several larger candidates were isolated (at a frequency of $\sim 1$ / $10,000)$ and found to represent two sizes of cDNA inserts of $\sim 960$ and $\sim 730 \mathrm{bp}$. DNA sequence analysis revealed that these cDNAs differ only in the length of the $5^{\prime}$ untranslated region and encode identical putative open reading frames. The homology between HNMP-1 and PMP22 is particularly striking in the four membrane-spanning regions (Fig. $1 A$ ).

To search for the mouse homolog of hnmp-1, a $318 \mathrm{bp}$ fragment of the human hnmp-1 cDNA generated with the same set of primers as above was used as a probe to screen cDNA clones from a library made from a RAW 264.7 mouse monocyte cell line (Neote et al., 1993). A cDNA was found with a 740 bp insert that encoded a protein of 163 amino acids that is nearly identical to human hnmp-1 (87\% nucleotide and $92.6 \%$ amino acid identity), shown in Figure $1 A$. Mouse candidate cDNAs were found at a frequency similar to that observed in the human library $(\sim 1 /$ $10,000)$. Only one size class of cDNA was identified for mouse hnmp-1. The strong conservation of hnmp-1 between species suggested an important biological role for this protein.

The entire $\sim 740$ bp mouse cDNA clone of hnmp-1 was used as a probe to screen a mouse $129 \lambda$ genomic DNA library. Hybridizing clones were characterized by restriction mapping, subcloning, and DNA sequencing. These studies revealed the structure of the mouse genomic locus (Fig. $1 B$ ). The mRNA is encoded by five exons, with the start site of translation in exon 2. The hnmp-1 genomic region encompasses $\sim 4.8 \mathrm{~kb}$. For comparative purposes, a schematic of the human pmp22 gene structure (Suter et al., 1994 ) is shown (Fig. 1B). The comparable position of exons 

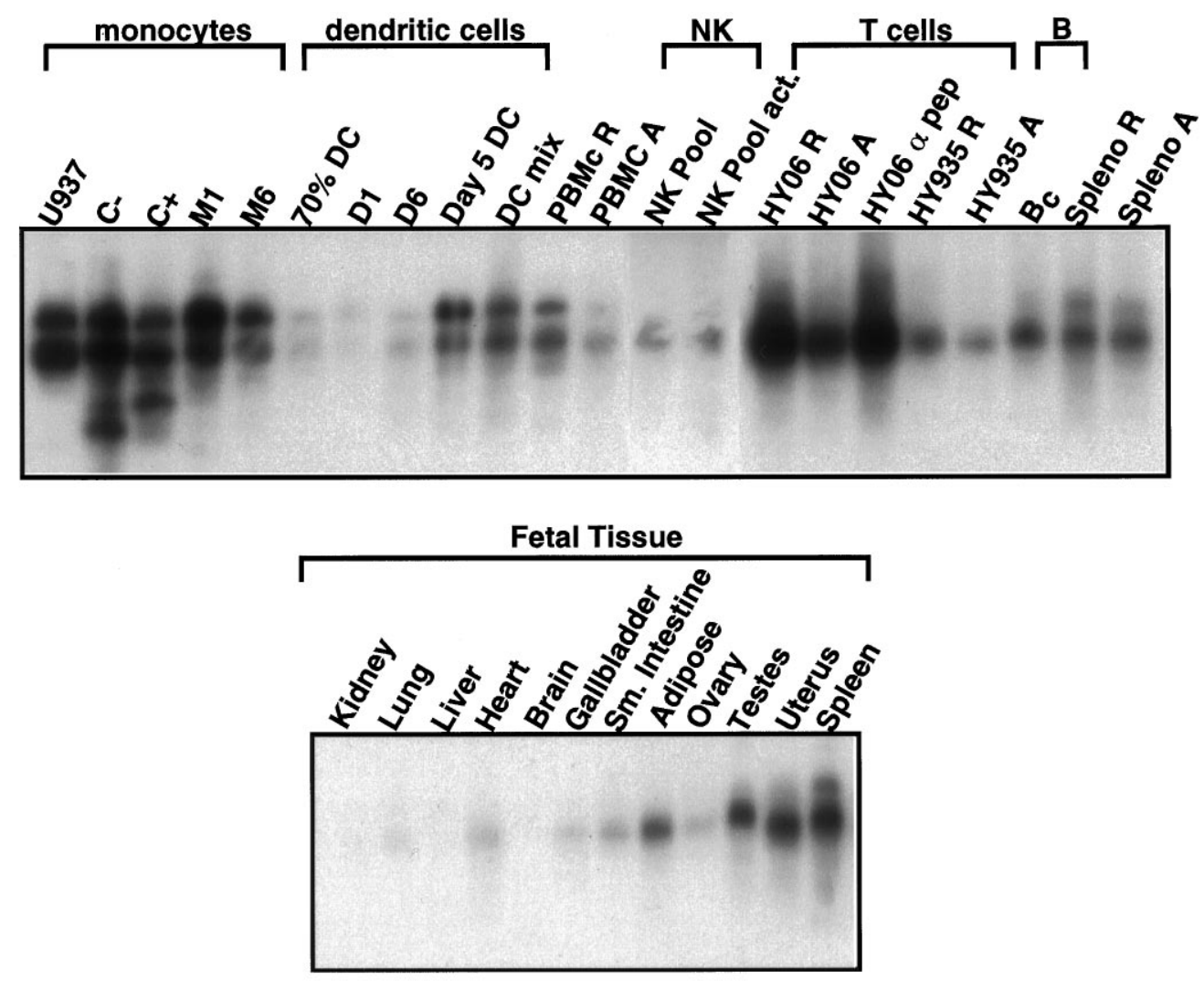

Figure 2. Cell and tissue distribution of hnmp-1 expression assessed via Southern analysis of human cDNA libraries. cDNA libraries were constructed from each cell or tissue type as described (Materials and Methods), and a Southern transfer of digested total library DNA (5 $\mu \mathrm{g} / \mathrm{lane}$ ) was probed with a fragment of human hnmp-1. Lanes represent $U 937$, human monocyte cell line; $C-$, human elutriated monocytes stimulated with $\gamma \mathrm{IFN}$ and LPS in the presence of blocking antibodies for IL-10 for 1, 2, 6, 12, and $24 \mathrm{hr}$ and pooled; $C+$, human elutriated monocytes stimulated with $\gamma \mathrm{IFN}$, LPS, and IL-10 for 1, 2, 6, 12, and $24 \mathrm{hr}$ and pooled; $M 1$, human elutriated monocytes stimulated for $1 \mathrm{hr}$ with LPS; M6, LPS stimulated for $6 \mathrm{hr} ; 70 \%$ DC, 70\% $\mathrm{CD} 1 \mathrm{a}^{+}$dendritic cells derived from $\mathrm{CD} 34^{+}$human cord blood stem cells by growth for $12 \mathrm{~d}$ in GM-CSF and tumor necrosis factor- $\alpha(\mathrm{TNF} \alpha) ; D 1,70 \%$ $\mathrm{CD}_{1}{ }^{+}$dendritic cells stimulated for $1 \mathrm{hr}$ with PMA and ionomycin; D6, $70 \%$ CD1a ${ }^{+}$, stimulated $6 \mathrm{hr}$ with phorbol myristate acetate and ionomycin; Day 5 DC, dendritic cells derived from human elutriated monocytes by growth in GM-CSF and IL-4 for $5 \mathrm{~d}$; $D C$ mix, dendritic cells derived from monocytes, stimulated with IL- $1 \alpha$ and TNF $\alpha$ for 4 and $16 \mathrm{hr}$ and pooled; $P B M c R$, human peripheral blood mononuclear cells; $P B M C A$, stimulated with anti-CD3 and PMA for 2, 6, and $12 \mathrm{hr}$ and pooled; NK pool, a pool of primary NK cell clones; NK pool act., stimulated $6 \mathrm{hr}$ with PMA and ionomycin; $H Y 06$, human Th1 T cell clone; HY06 A, stimulated with anti-CD3 and anti-CD28 for 2, 6, and $12 \mathrm{hr}$ and pooled; $H Y 06 \alpha$ pep, stimulated with a specific peptide rendering the cells anergic; HY935 R, human Th2 T cell clone; HY935 A, stimulated with anti-CD3 and anti-CD28 for 2, 6, and $12 \mathrm{hr}$ and pooled; $B c$, pool of EBV cell lines; Spleno R, total human splenocytes; Spleno A, stimulated with anti-CD40 and IL-4 for 2, 6, and 16 hr and pooled. Bottom panel shows libraries made from human fetal tissues ( 28 week). Probing replicate blots with human b-actin cDNA probe gave readily detectable $\sim 2.0 \mathrm{~kb}$ species in all lanes (data not shown). References available on request.

suggests an evolutionary expansion from common ancestral sequences.

\section{Cell type/tissue distribution of human hnmp-1}

To broadly assess the expression profile of HNMP-1, we performed a Southern analysis on a large panel of cDNA library DNAs ("library Southern"). This method was used to qualitatively assess the presence of HNMP-1 transcripts in various cell types, many of which were unavailable to us as mRNA. Equal amounts of DNA from each library were digested to release the inserts, and a Southern analysis was performed on these digested library DNAs using a 318 bp PCR-generated fragment of human hnmp-1 as a probe (Fig. 2). Two bands of $\sim 900$ and $\sim 700$ bp were detected in a number of human cDNA libraries; they correspond to the two full-length cDNA forms we have characterized. This analysis revealed that hnmp-1 is highly expressed in monocytes, with strong signals detected in cDNA libraries made from both a resting monocyte cell line (U937) and activated elutriated monocytes from which this clone was initially identified. HNMP-1 was also detected in libraries from dendritic cells derived from elu- triated monocytes by growth in GM-CSF and IL-4 but was only faintly detectable in dendritic cells derived from $\mathrm{CD} 34^{+}$stem cells. The cDNA was also present in libraries made from $\mathrm{T}$ cell lines, a pool of B cell lines, peripheral blood mononuclear cells, and total resting or anti-CD40/IL-4-stimulated splenocytes. Examination of cDNA libraries from fetal human tissue revealed that HNMP-1 is most strongly expressed in adipose tissue, testes, uterus, and spleen, very faintly visible in heart, gall bladder, small intestine, and ovary, and undetectable in kidney, lung, liver, and brain at the level of sensitivity afforded by this assay. The two size classes of cDNA were detected primarily in monocytes and dendritic cells, but only the $\sim 700$ bp species was represented in libraries from $\mathrm{T}$ cells, B cells, and some tissues.

\section{Mouse HNMP-1 expression}

HNMP-1 expression in adult and embryonic day 15 (E15) mouse tissues was determined by Northern analysis of total cellular RNA using a 380 bp restriction fragment. HNMP-1 was present in adult thymus, spleen, and lung, and at lower levels in kidney, heart, and intestine (Fig. $3 A$ ). In the mouse embryo, HNMP-1 
A

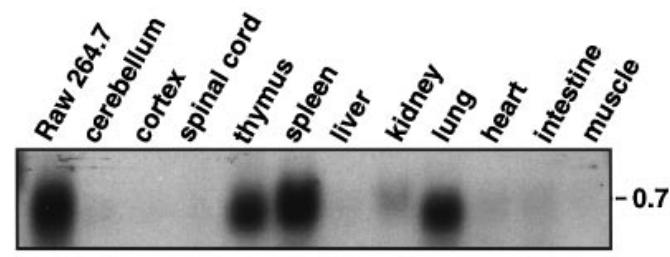

B

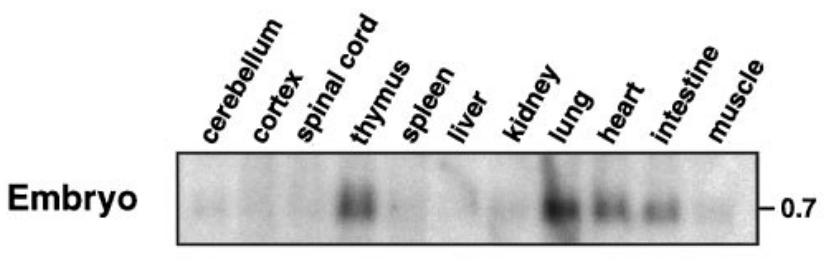

Et Br

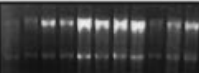

C

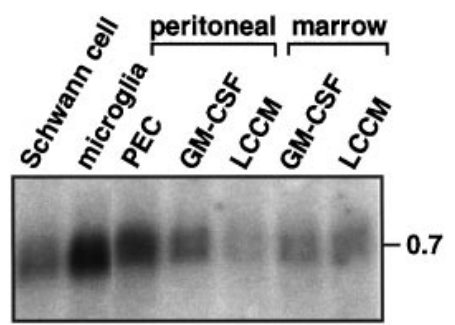

Et Br

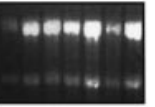

Figure 3. Expression of HNMP-1 in mouse tissues and cells. $A$, Total cellular RNA isolated from adult mouse tissues and probed with a mouse $380 \mathrm{~kb}$ HNMP-1 cDNA indicated a $0.6 \mathrm{~kb}$ messenger RNA species in spleen and thymus. Mouse RAW264.7, a monocyte cell line from which the mouse HNMP-1 was cloned, shown as a positive control. Ethidium bromide staining of the nylon blot indicates the amounts of RNA transferred. Film was exposed for 2 d. $B$, A wider distribution of HNMP-1 message was seen in total cellular RNA isolated from E15 tissues. During development, thymus, lung, heart, and intestine express HNMP-1 messenger RNA. Film was exposed for 2 d. $C$, Primary cells of the monocytic lineage, embryonic CNS microglia, and embryonic PNS Schwann cells expressed HNMP-1 message. HNMP-1 message was detected in peritoneal exudate cells $(P E C)$ and peritoneal and bone marrow-derived macrophage, which had been expanded in either GM-CSF or L cellconditioned medium $(L C C M)$. These monocyte populations were characterized as macrophage by FACS analysis using the lineage-specific markers CD11b and F4/80 (data not shown). Film was exposed for $18 \mathrm{hr}$.

was expressed in thymus, heart, intestine, and lung (Fig. 3B). Because HNMP-1 was cloned from a human monocyte library, the expression in mouse macrophage populations was examined, including freshly isolated PECs containing $\sim 40 \%$ macrophages, adherent macrophages derived from PECs and cultured in the presence of GM-CSF or L cell-conditioned media (LCCM), and adherent macrophages derived from whole bone marrow and cultured in the presence of GM-CSF or LCCM. These cultured populations were characterized as macrophage by Fluorescence Activated Cell Sorting (FACS) analysis with the F4/80 and
Anti-FLAG

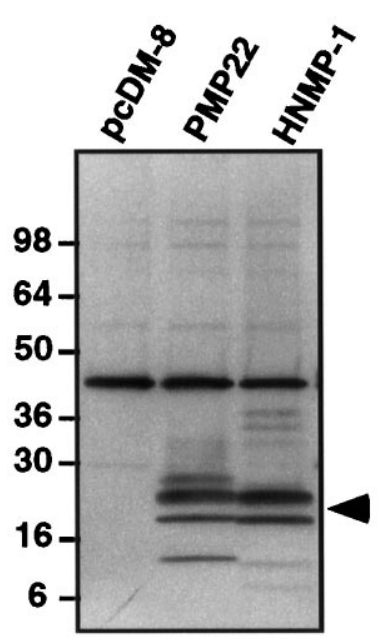

Anti-HNMP-1

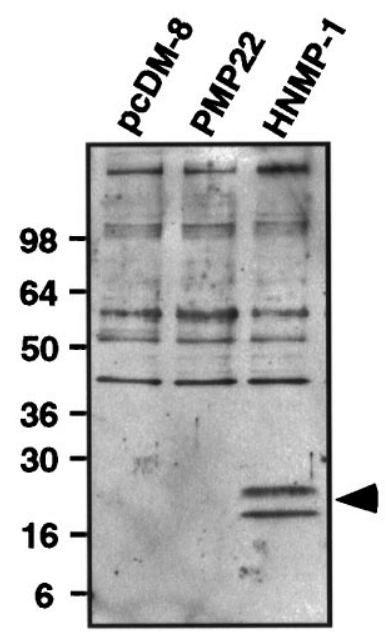

Figure 4. Characterization of affinity-purified antisera to HNMP-1 synthetic peptide. A doublet of 18 and $20 \mathrm{kDa}$ proteins was detected with anti-FLAG antibody in lysates of COP5 cells that had been transiently transfected with expression plasmids for HNMP-1 and PMP22 constructs fused to C-terminal FLAG-tags. Proteins of similar size were detected by affinity-purified antisera to HNMP-1 synthetic peptide in the lane transfected with the HNMP-1 construct. The HNMP-1-specific antisera does not cross-react with PMP22 protein.

CD11b markers (data not shown). Total RNA was also isolated from primary Schwann cells that were cultured from E15 DRG in the absence of mitogens and E15 microglia, the tissue macrophage of the CNS. These primary cells all expressed HNMP-1 RNA (Fig. 3C).

\section{Characterization of HNMP-1 in the developing nervous system}

Rabbit antisera directed against a synthetic peptide encoding the predicted second extracellular loop of mouse HNMP-1, an area of minimal homology, was generated, and peptide-specific IgG was affinity-purified using the synthetic peptide. A PMP22 antisera to a synthetic peptide encoding the presumptive first extracellular loop (Roa and Lupski, 1994) was also generated. To confirm the specificity of the antisera, mouse fibroblast COP5 cells were transiently transfected with fusion constructs of HNMP-1 and PMP22 and a C-terminal FLAG sequence so that expressed proteins could be detected by anti-FLAG antibody. Western blot analysis of cellular proteins using anti-flag antibody revealed HNMP-1 and PMP22 proteins of similar sizes, $\sim 20$ and $18 \mathrm{kDa}$ (Fig. 4A, arrow). Western blot analysis of similar cell lysates of HNMP-1 and PMP22 transfectants confirmed that antisera to the synthetic HNMP-1 peptide did not detect PMP22 (Fig. 4B, arrow). Similarly, antisera to PMP22 synthetic peptide did not cross-react with HNMP-1 (data not shown). The HNMP1-specific antisera permitted immunohistochemical analysis of neuron and Schwann cell acquisition of HNMP-1 protein.

To test the hypothesis that HNMP-1 expression was regulated in Schwann cell development, the time course of sciatic nerve myelination was examined at both the RNA level and the protein level. Although HNMP-1 messenger RNA was barely detectable in adult sciatic nerve, it was elevated at postnatal days 0-21 (Fig. 5). HNMP-1 message was also detected in E15 DRG.

Immunohistochemical analysis of HNMP-1 protein expression in DRG sensory neurons and motoneurons, whose axons reside in 


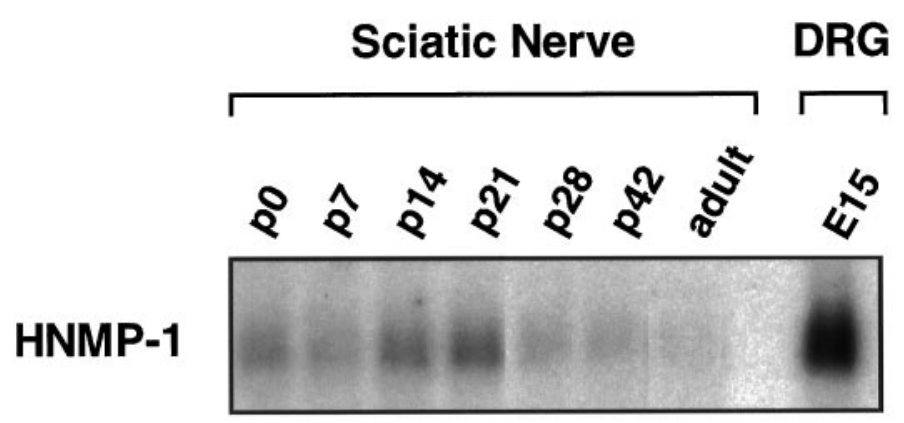

$\mathrm{Et} \mathrm{Br}$

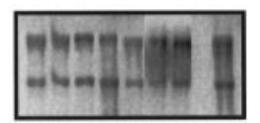

Figure 5. HNMP-1 expression in developing sciatic nerve. HNMP-1 message was barely detectable in total RNA isolated from adult sciatic nerve tissue. HNMP-1 message was elevated throughout the postnatal period of sciatic nerve myelination. A strong HNMP-1 message was also detected in E15 dorsal root ganglia. Ethidium bromide staining of the nylon blot indicates the amounts of RNA transferred. Film was exposed for $2 \mathrm{~d}$.

the sciatic nerve, was performed. Examination of E12 spinal cord indicated a lattice-like pattern of HNMP-1-positive fibers that extend from the central canal and articulate through differentiating spinal neurons and proliferating neuroblasts to the pia mater with a concentration in the floor plate (Fig. 6A, arrow). This immunoreactivity was blocked by preincubation of HNMP-1 antisera with HNMP-1 peptide (Fig. 6B). By E16, HNMP-1 immunoreactivity was seen in the somas of $\alpha$-motoneurons in ventral spinal cord as well as in the cores of fibers in the developing white matter (data not shown). This pattern of $\alpha$-motoneuron (arrows) HNMP-1 immunoreactivity was intensified in the adult lumbar spinal cord, along with axon-associated immunoreactivity in the cores of myelinated fiber tracts throughout the white matter (Fig. 6C). This adult cord HNMP-1 immunoreactivity was inhibited with HNMP-1 peptide (data not shown). The E12 DRG contained a small subset of cells whose somas and cell processes (arrows) were HNMP-1 positive (Fig. $6 D)$. This immunoreactivity was blocked by preincubation of HNMP-1 antisera with HNMP-1 peptide (Fig. $6 E$ ). In the adult lumbar 4 DRG, a subset of large sensory neurons expressed HNMP-1 protein along with fibers coursing between the cells (Fig. $6 F$ ). Thus, HNMP-1 protein is axon-associated in spinal cord fiber tracts and in subsets of sensory and $\alpha$-motoneuron somas whose axons reside in the sciatic nerve.

\section{HNMP-1 in naive sciatic nerve and sciatic nerve regeneration}

To test the hypothesis that HNMP-1 expression in regenerating sciatic nerve might recapitulate development, tissue distal to a crush injury was examined. HNMP-1 RNA was rapidly induced in distal injured nerve tissue (Fig. $7 A$ ). During the first 2 weeks after crush, HNMP-1 induction in injured nerve demonstrated an
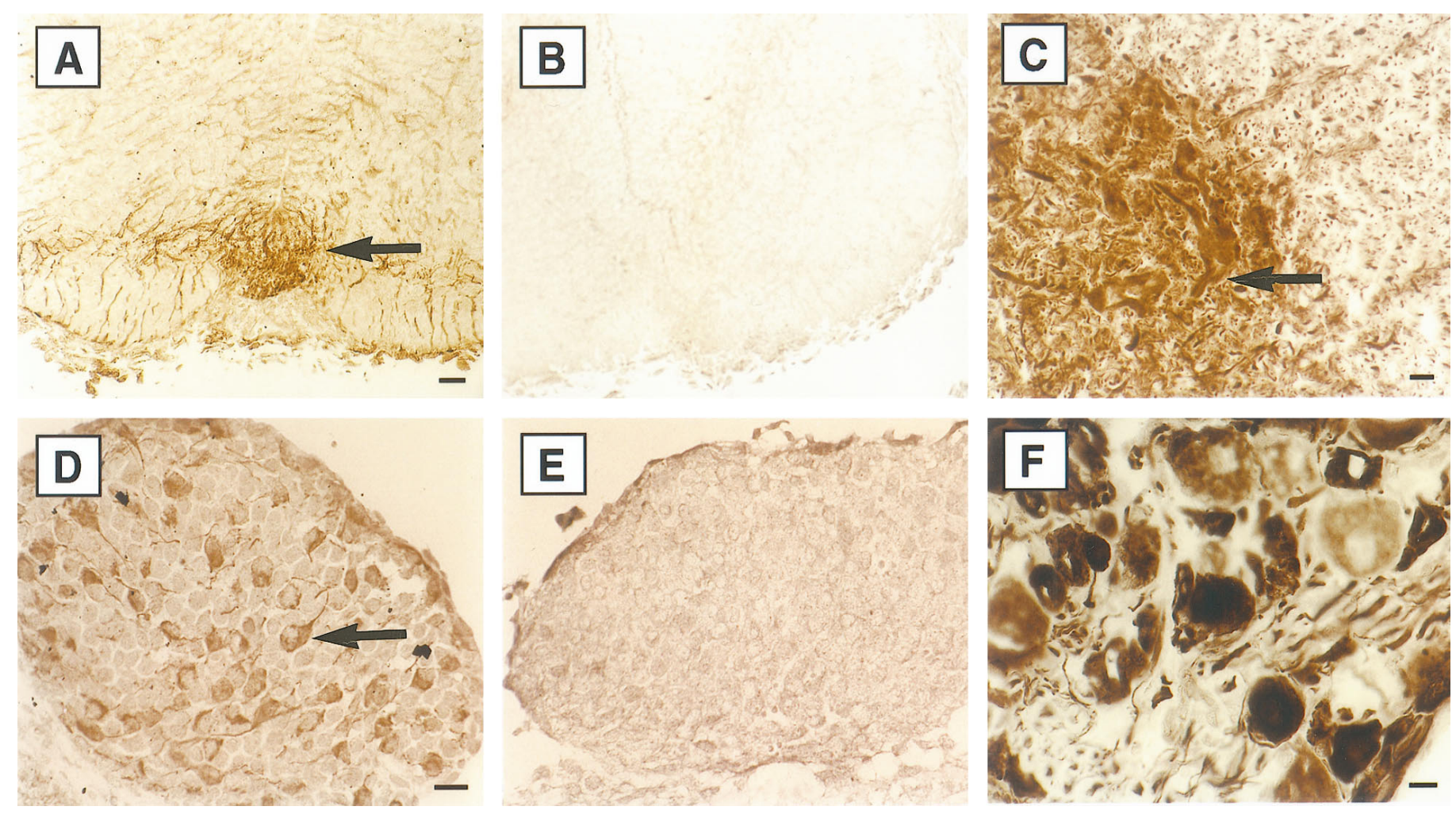

Figure 6. HNMP-1 protein expression in nervous system development. $A$, Frozen sections of E12 spinal cord $(n=8)$ incubated with affinity-purified antisera to HNMP-1 synthetic peptide revealed a lattice-like pattern of fibers that course from pia mater through differentiating neurons to the central canal. Intense HNMP-1 immunoreactivity was seen in the floorplate (arrow). B, Preincubation of antisera with HNMP-1-specific peptide blocked HNMP-1 immunoreactivity. $C$, Throughout development, HNMP-1 protein acquisition was observed in $\alpha$-motoneurons (arrow) and was axonassociated in fiber tracts of the white matter as seen here in the adult ventral spinal cord $(n=6)$. $D$, In E12 DRG $(n=16)$ there was a subset of HNMP-1-positive neurons (arrow). E, Preincubation of antisera with HNMP-1-specific peptide blocked HNMP-1 immunoreactivity. $F$, In the adult lumbar 4 DRG $(n=8)$, many large sensory neurons and articulating fibers were HNMP-1 positive. Scale bars, $10 \mu \mathrm{m}$. 
A

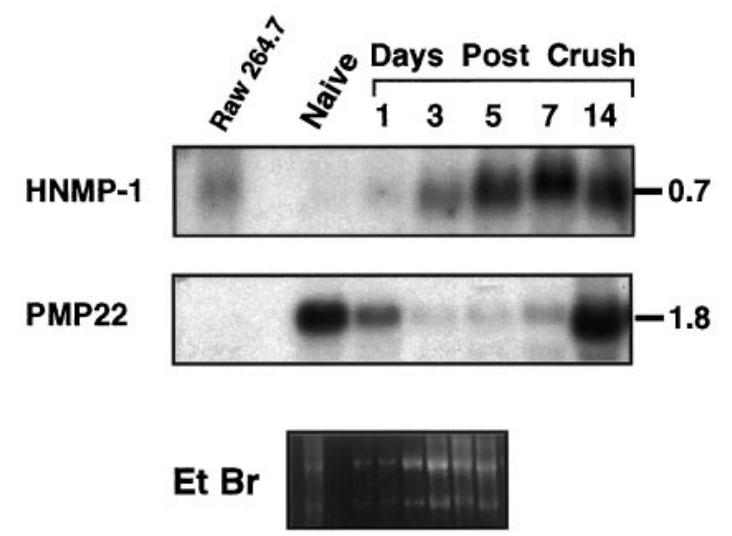

B

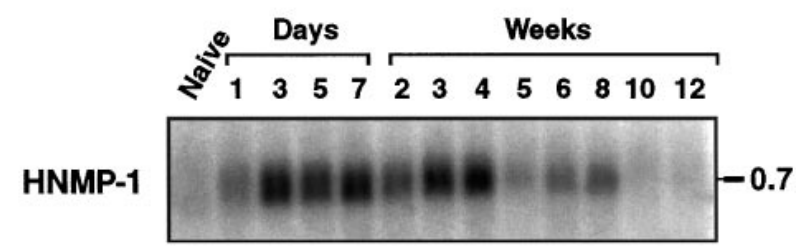

$\beta$ actin

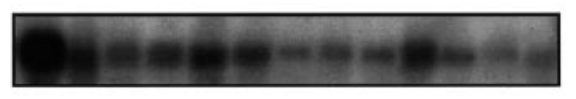

C

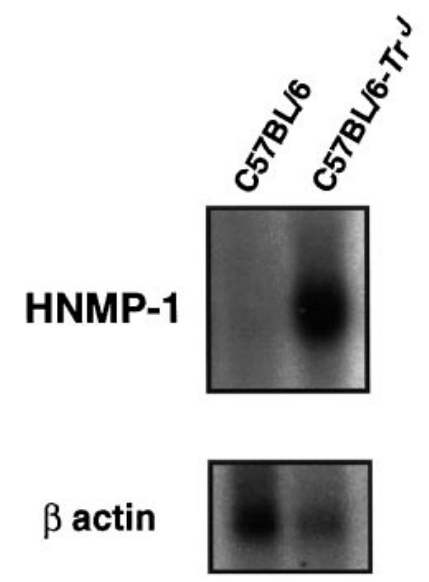

Figure 7. HNMP-1 expression in sciatic nerve regeneration. $A$, Northern analysis of total cellular RNA isolated from naive sciatic nerve and tissue distal to a crush injury indicated an immediate and sustained induction of HNMP-1 message. A comparison of HNMP-1 and PMP22 expression showed an inverse pattern of regulation. Immediate induction of HNMP-1 was in contrast to the downregulation of PMP22. $B$, A time course of HNMP-1 expression in distal nerve in response to crush indicated a sustained induction that returned to normal level after 8 weeks. $C$, Uninjured sciatic nerve from $\mathrm{C} 57 \mathrm{BL} / 6-\operatorname{Tr}^{\mathrm{J}}$ revealed a constituitively high level of HNMP-1 mRNA correlated to a Schwann cell demyelinating/hypomyelinating phenotype.

inverse correlation to the regulation of PMP22 in regeneration, which is rapidly downregulated after injury and returns to normal high expression by 2 weeks after crush (Fig. 7A). Elevation of HNMP-1 message continued for 8 weeks after crush, $\sim 4$ weeks beyond functional recovery and remyelination (Fig. $7 B$ ).
After we investigated the induction of HNMP-1 message and protein in the acutely injured sciatic nerve, we examined a mouse genetic model of chronic demyelination, the Trembler J (Henry and Sidman, 1988). The genetic defect in the C57BL/6-Tr ${ }^{\mathrm{J}}$ mouse, which exhibits Schwann cell proliferation and hypomyelination, has been mapped to a point mutation in the putative first transmembrane-spanning domain of the pmp22 gene (Suter et al., 1992a,b). Adult sciatic nerve total cellular RNA was isolated from C57BL/6- $\operatorname{Tr}^{\mathrm{J}}$ and $\mathrm{C} 57 \mathrm{BL} / 6$ control mice. HNMP-1 message was highly elevated in $\mathrm{C} 57 \mathrm{BL} / 6-\operatorname{Tr}^{\mathrm{J}}$ (Fig. $7 C$ ), similar to that observed in sciatic nerve distal to injury (Fig. $7 A, B$ ).

To determine HNMP-1 protein distribution in the adult sciatic nerve, immunohistochemical analyses of naive and injured nerve were performed. In naive adult longitudinal nerve tissue sections, HNMP-1 appeared to be axon-associated with undulating positive fibers that were tangentially sectioned (Fig. $8 A$ ). This reactivity was blocked by HNMP-1 antisera preincubation with HNMP-1 synthetic peptide (Fig. $8 B$ ) but not by PMP22 synthetic peptide preincubation (Fig. $8 C$ ). In sciatic nerve cross section, the HNMP-1 protein immunoreactivity was evident in the axon core, whereas surrounding myelin sheaths were uniformly negative (Fig. 8D). The axon-associated immunoreactivity in the nerve was similar to the axon-associated HNMP-1 staining pattern observed in adult spinal cord (Fig. 6C).

At 1 week after crush, when HNMP-1 message was highly induced in distal nerve (Fig. $7 A, B$ ), HNMP-1 protein in distal nerve was observed in areas that surround the degenerating myelin sheaths, a location consistent with proliferating Schwann cells (Fig. 8E). Axon-associated HNMP-1 immunoreactivity was not seen. At 3 weeks after crush, axon-associated HNMP-1 immunoreactivity in the core of myelin sheaths was reestablished (Fig. $8 F$ ). By 6 weeks after crush, when HNMP-1 message was still elevated, the normal adult axon-associated HNMP-1 immunoreactivity (Fig. $8 A, D$ ) was observed (data not shown). The observed patterns of HNMP-1 immunoreactivity in regenerating sciatic nerve are consistent with a potential role for this molecule during active myelination.

\section{DISCUSSION}

Investigation of novel genes expressed in human monocytes led to the cloning and characterization of hnmp-1, a gene that encodes a presumed tetra-membrane-spanning protein that shows a $44 \%$ amino acid homology to PMP22. In human, expression was demonstrated in various hematopoietic-derived cells and was especially strong in cells of the monocytic lineage. Expression in dendritic cells, derived from CD34 ${ }^{+}$cord blood stem cells, was minimal; however, dendritic cells derived from elutriated human monocytes gave much stronger signals. Human fetal splenic tissue gave a strong signal, as would be expected from the cell line panel examined. In correspondence with the Southern library expression, mouse hnmp-1 mRNA was detected in adult murine hematopoietic tissues, such as spleen and thymus. Fetal tissue from the mouse and human were similar for expression in the thymus, but also showed a broader distribution than adult tissues. Because primary macrophage cell cultures derived from hematopoietic locations were also positive for expression, it is possible that hematopoietic cells such as engrafting tissue macrophages may contribute to the signals in some of the embryonic tissues not typically considered hematopoietic.

Because of the homology to PMP22 and therefore the inference of potential nervous system biology, as well as expression in Schwann cells and microglia, a detailed analysis of HNMP-1 in 

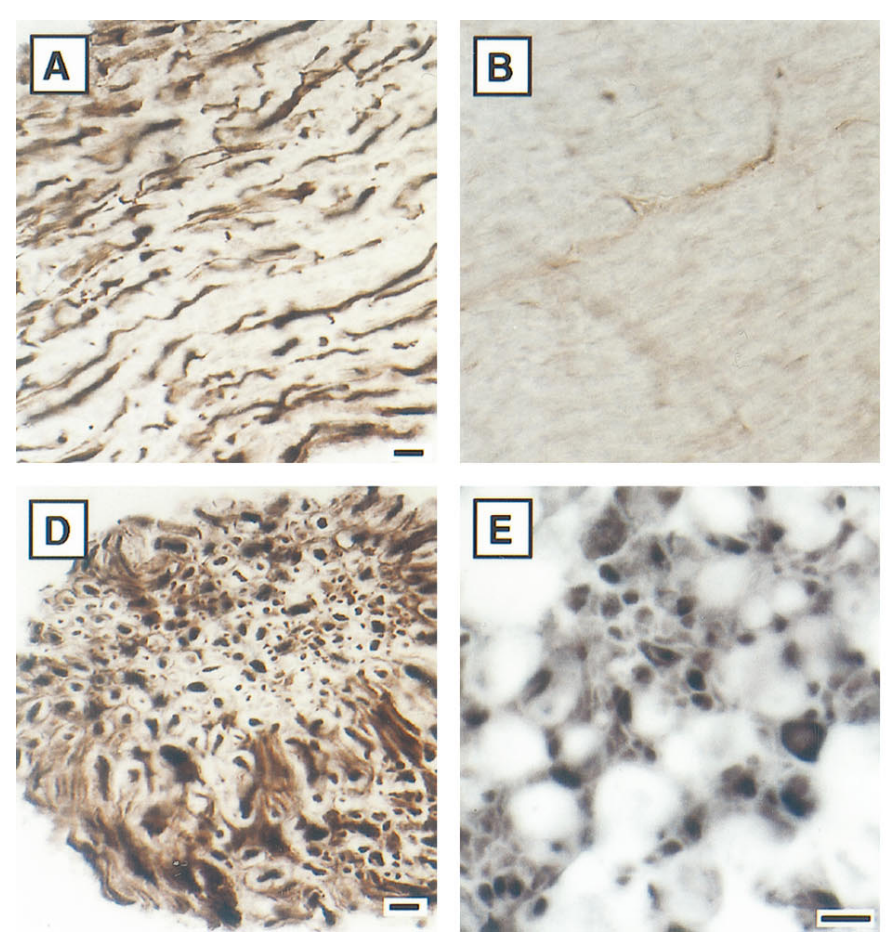

the mouse nervous system was undertaken. HNMP-1 was first detected in E12 lumbar spinal cord as a complex scaffold-like immunoreactivity that extends from the central canal to the pia mater (Fig. 6A). A possible cellular source of this HNMP-1 immunoreactivity are the neuroepithelial cells residing at the central canal. It has been shown that in the assembly of the CNS, neuroepithelia (Yaginuma et al., 1990), glia (Gregory et al., 1988), and pioneer neurons (Bastiani et al., 1984) provide guidance scaffolding for migrating and differentiating neuroblasts. Earlier examination of the developing spinal cord will be necessary to identify absolutely the cellular source of HNMP-1 protein. HNMP-1-positive $\alpha$-motoneurons in the ventral cord were observed at E16 and postnatal day 16 (data not shown). In the adult ventral spinal cord, $\alpha$-motoneuron soma and axonassociated HNMP-1 immunoreactivity in the majority of ascending spinal tracts was observed (Fig. 6C). At E12, when commitment to particular sensory lineages is being determined (Snider and Wright, 1996), a subset of DRG neuronal somas and neurite extensions were HNMP-1 positive (Fig. $6 D$ ). In the adult lumbar DRG, a subset of sensory soma and axons expressed HNMP-1 (Fig. $6 F$ ). Early neuronal acquisition of HNMP-1 protein in PNS (E12 DRG sensory neurons) and CNS (E16 spinal cord $\alpha$-motoneurons) preceded glia expression. As has been shown for PMP22 (Parmantier et al., 1995), the HNMP-1 immunoreactivity is present in neural somas even though the predicted structure is that of a membrane-spanning protein. In peripheral nerve development, axons are accompanied by Schwann cells as they extend to their target organs (Keynes, 1987). HNMP-1 message was detected in primary embryonic Schwann cells (Fig. 3C) and during postnatal myelination of the sciatic nerve (Fig. 5). HNMP-1 expression by the neuronal components and the glia of the myelinating sciatic nerve suggest a significant role for this protein in PNS developmental biology.

Specific axon-associated signals are postulated in initiating the Schwann cell myelination program (Mirsky and Jessen, 1996). It is important to note that in null mutants of each of the major

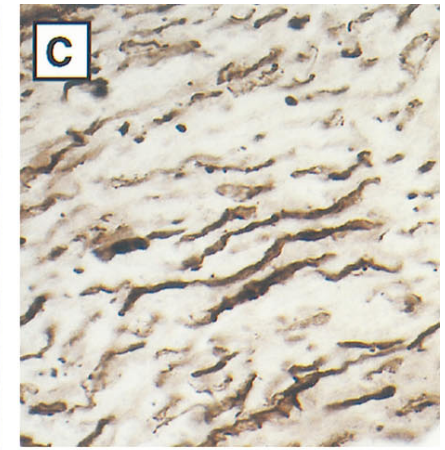

Figure 8. HNMP-1 protein expression in naive and regenerating sciatic nerve. $A$, Immunohistochemical analysis of HNMP-1 protein in longitudinal frozen sections of normal adult sciatic nerve revealed an axon-associated pattern in fibers cut tangentially. $B$, Preincubation of antisera with HNMP-1specific peptide blocked HNMP-1 immunoreactivity. $C$, Preincubation of antisera with PMP22-specific peptide did not inhibit HNMP-1 immunoreactivity. $D$, A fascicle of normal sciatic nerve cut in cross section revealed HNMP-1 immunoreactivity associated with the majority of axons of myelinated fibers. $E$, In distal sciatic nerve 1 week after crush, HNMP-1-positive cells were detected surrounding myelin sheath profiles. $F$, At 3 weeks after crush, distal sciatic nerve tissue revealed HNMP-1 immunoreactivity restored to the axon-associated pattern observed in naive sciatic nerve and continued expression in occasional cells surrounding myelin sheaths. Scale bar, $20 \mu \mathrm{m}$. myelin proteins, MBP, $\mathrm{P}_{0}$, and PMP22 (Roach et al., 1983; Giese et al., 1992; Adlkofer et al., 1995), and in doubly mutant mice lacking both $\mathrm{P}_{0}$ and MBP (Martini et al., 1995), Schwann cells do myelinate. This suggests that the known myelin proteins are not the critical molecules mediating initiation of myelination through axon-Schwann cell membrane aposition. Temporal expression of HNMP-1 in both growing axons and differentiating Schwann cells during PNS development suggests the involvement of possible homotypic signaling.

Peripheral nerve regeneration is thought to recapitulate development and has been a useful tool in discovering the mechanisms that contribute to successful axon regrowth in the PNS (Bridge et al., 1994). Pmp22 was discovered in a rat sciatic nerve regeneration paradigm as an mRNA that was repressed in nerve distal to the crush (DeLeon et al., 1991). Sciatic nerve crush in the mouse permitted an analysis of HNMP-1 regulation. A rapid and sustained elevation of HNMP-1 message was observed in nerve distal to the injury (Fig. $7 A, B$ ). The induced HNMP-1 message correlated with a shift from the axon-associated HNMP-1 immunoreactivity observed in naive adult nerve (Fig. $8 A, D$ ) to HNMP-1 protein detected in areas containing proliferating Schwann cells (Fig. 8E). HNMP-1 message remained elevated long after functional recovery and the return to normal, preinjury levels of the myelin proteins PMP22, $\mathrm{P}_{0}$, and MBP (Bascles et al., 1992; Kuhn et al., 1993). A similar and constituitively elevated HNMP-1 message was observed in sciatic nerve of Trembler J mice (Fig. 7C), which is in a chronic state of demyelination/ hypomyelination. Thus, HNMP-1 induction in the injured sciatic nerve is not similar to that observed in the developing nerve, which is consistent with postnatal myelination (Fig. 5); rather, the immediate and sustained HNMP-1 expression in injured nerve suggests an early involvement in Schwann cell proliferation and a sustained role in restructuring after injury.

There is ample evidence of macrophage production of Schwann cell stimulatory and proliferation factors including apolipoprotein E (Ignatius et al., 1987) and IL-1 (Huemann et al., 
1987a,b; Rotshenker et al., 1992) that directly influence Schwann cell function. In response to sciatic nerve crush, resident macrophages migrate to the site of injury and remain in elevated numbers for at least 6 weeks (Raivich and Kreutzberg, 1993). It is not known whether macrophages signal Schwann cells directly through membrane-membrane interactions. Because HNMP-1 message was detected in both cell types (Fig. 3C), which are activated in response to PNS injury, further investigation of macrophage-Schwann cell interactions in this context is necessary.

PMP22 is a member of a growing family of tetra-spanning membrane proteins (DeLeon et al., 1991; Spreyer et al., 1991; Welcher et al., 1991). Another member of this family, MP20 (lens-specific membrane protein), is exclusively expressed in the lens and may function in stabilizing junctional plaques (Kumar et al., 1993). EMP-1, an epithelial membrane protein, is coexpressed with PMP22 in most tissues, with enriched levels in gastrointestinal organs (Taylor et al., 1995). The data on these membrane proteins suggest involvement in cell-cell interactions, including proliferative signaling in the basal crypts of the ileum (Taylor et al., 1995) and growth arrest (Manfioletti et al., 1990). Whether the mechanism of signaling in this cell-cell contact is through homotypic interaction has not been determined. HNMP-1 was cloned in cells of the hematopoietic lineage and is expressed in diverse monocyte populations. Cell contact between monocytes and other immune system cell types signals an amplification of their inflammatory response. The extent to which tetra-spanning membrane components may contribute to these functions is being explored. The data presented here of HNMP-1 expression in developing CNS and PNS neuronal populations and in Schwann cells during neonatal myelination and remyelination of the injured sciatic nerve implies a significant role in neuron-Schwann cell contact and functional synergy. An analogous role for HNMP-1 in hematopoiesis may emerge from a functional analysis of monocyte development and inflammatory responses.

Note added in proof: While this manuscript was under review, two manuscripts reported the cloning of a human cDNA similar (two amino acid differences) (Taylor and Suter, Gene 175:115120, 1996) or identical (Ben-Porath and Benvenisty, Gene 183: $69-75,1996)$ to hnmp-1.

\section{REFERENCES}

Adlkofer K, Martini R, Aguzzi A, Zielasek J, Toyka KV, Suter U (1995) Hypermyelination and demyelinating peripheral neuropathy in Pmp22deficient mice. Nat Genet 11:274-280.

Altschul SF, Gish W, Miller W, Myers EW, Lipman DJ (1990) Basic local alignment search tool. J Mol Biol 215:403-410.

Anderson DJ (1989) The neural crest cell lineage problem: neuropoiesis? Neuron 3:1-12.

Arai KI, Lee F, Miyajima A, Miyatake S, Arai N, Yokota T (1990) Cytokines: coordinators of immune and inflammatory responses. Annu Rev Biochem 59:783-836.

Baechner D, Liehr T, Hameister H, Altenberger H, Grehl H, Suter U, Rautenstrauss B (1995) Widespread expression of the peripheral myelin protein-22 gene (pmp22) in neural and non-neural tissues during murine development. J Neurosci Res 42:733-741.

Bascles L, Bonnet J, Garbay B (1992) Expression of the PMP-22 gene in Trembler mutant mice: comparison with the other myelin protein genes. Dev Neurosci 14:336-341.

Bastiani MJ, Raper JA, Goodman CS (1984) Pathfinding by neuronal growth cones in grasshopper embryos. III. Selective affinity of the $\mathrm{G}$ growth cone for the $\mathrm{P}$ cells within the $\mathrm{A} / \mathrm{P}$ fascicle. J Neurosci 4:2311-2328.

Bergoffen J, Scherer SS, Wang S, Scott MO, Bone LJ, Paul DL, Chen K, Lensch MW, Chance PF, Fischbeck KH (1993) Connexin mutations in X-linked Charcot-Marie-Tooth disease. Science 262:2039-2042.
Bergsteinsdottir K, Kingston A, Mirsky R, Jessen KR (1991) Rat Schwann Cells produce interleukin-1. J Neuroimmunol 34:15-23.

Bolin LM, Shooter EM (1993) Neurons regulate Schwann cell genes by diffusible molecules. J Cell Biol 123:237-243.

Bolin LM, Verity AN, Silver JE, Shooter EM, Abrams JS (1995) Interleukin-6 production by Schwann cells and induction in sciatic nerve injury. J Neurochem 64:850-858.

Bridge PM, Ball DJ, Mackinnon SE, Nakao Y, Brandt K, Hunter DA, Hertl C (1994) Nerve crush injuries: a model for axonotmesis. Exp Neurol 127:284-290.

Carnahan JF, Patel DR, Miller JA (1994) Stem cell factor is a neurotrophic factor for neural crest-derived chick sensory neurons. J Neurosci 14:1433-1440.

Chance PF, Fischbeck KH (1994) Molecular genetics of Charcot-MarieTooth disease and related neuropathies. Hum Mol Genet 3:1503-1507.

Chance PF, Lupski JR (1994) Inherited neuropathies: Charcot-MarieTooth disease and related disorders. Baillieres Clin Neurol 3:373-385.

Cheema SS, Richards L, Murphy M, Bartlett PF (1994) Leukemia inhibitory factor prevents the death of axotomised sensory neurons in the dorsal root ganglia of the neonatal rat. J Neurosci Res 37:213-218.

Dailey L, Basilico C (1985) Sequences in the polyomavirus DNA regulatory region involved in viral DNA replication and early gene expression. J Virol 54:739-749.

Davis S, Aldrich TH, Stahl N, Pan L, Taga T, Kishimoto T, Ip NY, Yancopoulos GD (1993) LIFR beta and gp130 as heterodimerizing signal transducers of the tripartite CNTF receptor. Science 260:1805-1808.

DeLeon M, Welcher AA, Suter U, Shooter EM (1991) Identification of transcriptionally regulated genes after sciatic nerve injury. J Neurosci Res 29:437-448.

Dinarello CA (1989) The endogenous pyrogens in host-defense interactions. Hosp Pract [Off] 24:111-115.

Gearing DP, Comeau MR, Friend DJ, Gimpel SD, Thut CJ, McGourty J, Brasher KK, King JA, Gillis S, Mosley B, Ziegler SF, Cosman D (1992) The IL-6 signal transducer, gp130: an oncostatin M receptor and affinity converter for the LIF receptor. Science 255:1434-1437.

Giese KP, Martini R, Lemke G, Soriano P, Schachner M (1992) Mouse $\mathrm{P} 0$ gene disruption leads to hypomyelination, abnormal expression of recognition molecules, and degeneration of myelin and axons. Cell 71:565-576.

Gregory WA, Edmondson JC, Hatten ME, Mason CA (1988) Cytology and neuron-glial apposition of migrating cerebellar granule cells in vitro. J Neurosci 8:1728-1738.

Hawk CT, Leary SL (1995) Formulary for laboratory animals. Ames, IA: Iowa State UP.

Hayasaka K, Himoro M, Sato W, Takada G, Uyemura K, Shimizu N, Bird TD, Conneally PM, Chance PF (1993) Charcot-Marie-Tooth neuropathy type $1 \mathrm{~B}$ is associated with mutations of the myelin $\mathrm{P} 0$ gene. Nat Genet 5:31-34.

Henry EW, Sidman RL (1988) Long lives for homozygous trembler mutant mice despite virtual absence of peripheral nerve myelin. Science 241:344-346.

Hibi M, Murakami M, Saito M, Hirano T, Taga T, Kishimoto T (1990) Molecular cloning and expression of an IL-6 signal transducer, gp130. Cell 63:1149-1157.

Hirata T, Morii E, Morimoto M, Kasugai T, Tsujimura T, Hirota S, Kanakura Y, Nomura S, Kitamura Y (1993) Stem cell factor induces outgrowth of c-kit-positive neurites and supports the survival of c-kitpositive neurons in dorsal root ganglia of mouse embryos. Development 119:49-56.

Huemann R, Korsching S, Bandtlow C, Thoenen H (1987a) Changes in nerve growth factor synthesis in nonneuronal cells in response to sciatic nerve transection. J Cell Biol 104:1623-1631.

Huemann R, Lindholm D, Bandtlow C, Meyer M, Radeke MJ, Misko TP, Shooter E, Thoenen H (1987b) Differential regulation of mRNA encoding nerve growth factor and its receptor in rat sciatic nerve during development, degeneration, and regeneration: role of macrophages. Proc Natl Acad Sci USA 84:8735-8739.

Ignatius MJ, Gebicke HP, Pitas RE, Shooter EM (1987) Apolipoprotein E in nerve injury and repair. Prog Brain Res 71:177-184.

Keynes RJ (1987) Schwann cells during neural development and regeneration: leaders or followers? Trends Neurosci 10:137-139.

Kuhn G, Lie A, Wilms S, Muller HW (1993) Coexpression of PMP22 gene with $\mathrm{MBP}$ and $\mathrm{P} 0$ during de novo myelination and nerve repair. Glia 8:256-264. 
Kumar NM, Jarvis LJ, Tenbroek E, Louis CF (1993) Cloning and expression of a major rat lens membrane protein, MP20. Exp Eye Res 56:35-43.

Lemke G (1993) The molecular genetics of myelination: an update. Glia 7:263-271.

Lemke G, Axel R (1985) Isolation and sequence of a cDNA encoding the major structural protein of peripheral myelin. Cell 40:501-508.

Litton MJ, Sander B, Murphy E, O’Garra A, Abrams JS (1994) Early expression of cytokines in lymph nodes after treatment in vivo with Staphylococcus enterotoxin B. J Immunol Methods 175:47-58.

Manfioletti G, Ruaro ME, Del SG, Philipson L, Schneider C (1990) A growth arrest-specific (gas) gene codes for a membrane protein. Mol Cell Biol 10:2924-2930.

Martini R, Mohajeri MH, Kasper S, Giese KP, Schachner M (1995) Mice doubly deficient in the genes for $\mathrm{P} 0$ and myelin basic protein show that both proteins contribute to the formation of the major dense line in peripheral nerve myelin. J Neurosci 15:4488-4495.

Martinou JC, Martinou I, Kato AC (1992) Cholinergic differentiation factor $(\mathrm{CDF} / \mathrm{LIF})$ promotes survival of isolated rat embryonic motoneurons in vitro. Neuron 8:737-744.

Metcalf D (1991) Control of granulocytes and macrophages: molecular, cellular, and clinical aspects. Science 254:529-533.

Mirsky R, Jessen KJ (1996) Schwann cell development, differentiation and myelination. Curr Opin Neurobiol 6:89-96.

Neote K, DiGregorio D, Mak JY, Horuk R, Schall TJ (1993) Molecular cloning, functional expression, and signaling characteristics of a $\mathrm{C}-\mathrm{C}$ chemokine receptor. Cell 72:415-425.

Neuhaus J, Fedoroff S (1994) Development of microglia in mouse neopallial cell cultures. Glia 11:11-17.

Parmantier E, Cabon F, Braun C, D’Urso D, Muller HW, Zalc B (1995) Peripheral myelin protein-22 is expressed in rat and mouse brain and spinal cord motoneurons. Eur J Neurosci 7:1080-1088.

Patel PI, Lupski JR (1994) Charcot-Marie-Tooth disease: a new paradigm for the mechanism of inherited disease. Trends Genet 10:128-133.

Patel PI, Roa BB, Welcher AA, Schoener SR, Trask BJ, Pentao L, Snipes GJ, Garcia CA, Francke U, Shooter EM, Lupski JR, Suter U (1992) The peripheral myelin gene PMP-22/GAS-3 is duplicated in CharcotMarie-Tooth disease type 1A. Nat Genet 1:166-170.

Patterson PH (1992) The emerging neuropoietic cytokine family: first CDF/LIF, CNTF and IL-6; next ONC, MGF, GCSF. Curr Opin Neurobiol 2:94-97.

Raivich G, Kreutzberg GW (1993) Peripheral nerve regeneration: role of growth factors and their receptors. Int J Dev Neurosci 11:311-324.

Roa BB, Lupski JR (1994) Molecular genetics of Charcot-Marie-Tooth neuropathy. Adv Hum Genet 22:117-152.

Roa BB, Garcia CA, Pentao L, Killian JM, Trask BJ, Suter U, Snipes GJ, Ortiz LR, Shooter EM, Patel PI, Lupski JR (1993a) Evidence for a recessive PMP22 point mutation in Charcot-Marie-Tooth disease type 1A. Nat Genet 5:189-194.

Roa BB, Garcia CA, Suter U, Kulpa DA, Wise CA, Mueller J, Welcher AA, Snipes GJ, Shooter EM, Patel PI, Lupski JR (1993b) CharcotMarie-Tooth disease type 1A: association with a spontaneous point mutation in the PMP22 gene. N Engl J Med 329:96-101.

Roach A, Boylan K, Horvath S, Prusiner SB, Hood LE (1983) Characterization of cloned cDNA representing rat myelin basic protein: ab- sence of expression in brain of shiverer mutant mice. Cell 34:799-806.

Rotshenker S, Aamar S, Barak V (1992) Interleukin-1 activity in lesioned peripheral nerve. J Neuroimmunol 39:75-80.

Sambrook J, Fritsch EF, Maniatis T (1989) Molecular cloning. Cold Spring Harbor, NY: Cold Spring Harbor Laboratory.

Scherer SS, Deschenes SM, Xu YT, Grinspan JB, Fischbeck KH, Paul DL (1995) Connexin32 is a myelin-related protein in the PNS and CNS. J Neurosci 15:8281-8294.

Snider WD, Wright DE (1996) Neurotrophins cause new sensation. Neuron 16:229-232.

Snipes GJ, Suter U, Welcher AA, Shooter EM (1992) Characterization of a novel peripheral nervous system myelin protein (PMP-22/SR13). J Cell Biol 117:225-238.

Snipes GJ, Suter U, Shooter EM (1993) Human peripheral myelin protein-22 carries the L2/HNK-1 carbohydrate adhesion epitope. J Neurochem 61:1961-1964.

Spreyer P, Kuhn G, Hanemann CO, Gillen C, Schaal H, Kuhn R, Lemke G, Muller HW (1991) Axon-regulated expression of a Schwann cell transcript that is homologous to a "growth arrest-specific" gene. EMBO J 10:3661-3668.

Stoll G, Griffin JW, Cy L, Trapp BB (1989) Wallerian degeneration in the peripheral nervous system: participation of both Schwann cells and macrophages. J Neurocytol 18:671-683.

Suter U, Snipes GJ, Schoener SR, Welcher AA, Pareek S, Lupski JR, Murphy RA, Shooter EM, Patel PI (1994) Regulation of tissuespecific expression of alternative peripheral myelin protein-22 (PMP22) gene transcripts by two promoters. J Biol Chem 269:795-808.

Suter U, Welcher AA, Ozcelik T, Snipes GJ, Kosaras B, Francke U, Billings GS, Sidman RL, Shooter EM (1992a) Characterization of a novel peripheral nervous system myelin protein (PMP-22/SR13). J Cell Biol 117:225-238.

Suter U, Welcher AA, Ozcelik T, Snipes GJ, Kosaras B, Francke U, Billings-Gagliardi S, Sidman RL, Shooter EM (1992b) Trembler mouse carries a point mutation in a myelin gene. Nature 356:241-244.

Taga T, Hibi M, Hirata Y, Yamasaki K, Yasukawa K, Matsuda T, Hirano $\mathrm{T}$, Kishimoto $\mathrm{T}$ (1989) Interleukin-6 triggers the association of its receptor with a possible signal transducer, gp130. Cell 58:573-581.

Taylor V, Welcher AA, Program AE, Suter U (1995) Epithelial membrane protein-1, peripheral myelin protein 22, and lens membrane protein 20 define a novel gene family. J Biol Chem 270:28824-28833.

Valentijn LJ, Baas F, Wolterman RA, Hoogendijk JE, van den Bosch N, Zorn I, Gabreels-Festen A, de Visser M, Bolhuis PA (1992) Identical point mutations of PMP-22 in Trembler-J mouse and Charcot-MarieTooth disease type 1A. Nat Genet 2:288-291.

Welcher AA, Suter U, De Leon M, Snipes GJ, Shooter EM (1991) A myelin protein is encoded by the homologue of a growth arrest-specific gene. Proc Natl Acad Sci USA 88:7195-7199.

Yaginuma H, Shiga T, Homma S, Ishihara R, Oppenheim RW (1990) Identification of early developing axon projections from spinal interneurons in the chick embryo with a neuron specific beta-tubulin antibody: evidence for a new "pioneer" pathway in the spinal cord. Development 108:705-716.

Zhang BT, Hikawa N, Horie H, Takenaka T (1995) Mitogen induced proliferation of isolated adult mouse Schwann cells. J Neurosci Res 41:648-654. 